\title{
Insights into pH regulatory mechanisms in mediating spermatozoa functions
}

\author{
Abhishek Kumar Mishra ${ }^{1}$, Akshay Kumar ${ }^{2}$, Dilip Kumar Swain ${ }^{3}$, Sarvajeet Yadav ${ }^{3}$ and Rajesh Nigam ${ }^{1}$
}

1. College of Biotechnology, U.P. Pandit Deendayal Upadhayaya Pashu Chikitsa Vigyan Vishwavidyalaya Evam Go Anusandhan Sansthan, Mathura - 281 001, Uttar Pradesh, India; 2. Department of Gynaecology and Obstetrics, College of Veterinary Sciences and Animal Husbandry, U.P. Pandit Deendayal Upadhayaya Pashu Chikitsa Vigyan Vishwavidyalaya Evam Go Anusandhan Sansthan, Mathura - 281 001, Uttar Pradesh, India; 3. Department of Physiology, College of Veterinary Sciences and Animal Husbandry, U.P. Pandit Deendayal Upadhayaya Pashu Chikitsa Vigyan Vishwavidyalaya Evam Go Anusandhan Sansthan, Mathura - 281 001, Uttar Pradesh, India.

Corresponding author: Dilip Kumar Swain, e-mail: dilip_swain@yahoo.com

Co-authors: AKM: mishraakvet@gmail.com, AK: akshay.rajawat@gmail.com, SY: yadavsarvajeet24@gmail.com, RN: dr_rajesh2005@rediffmail.com

Received: 13-02-2018, Accepted: 17-05-2018, Published online: 26-06-2018

doi: 10.14202/vetworld.2018.852-858 How to cite this article: Mishra AK, Kumar A, Swain DK, Yadav S, Nigam R (2018) Insights into $\mathrm{pH}$ regulatory mechanisms in mediating spermatozoa functions, Veterinary World, 11(6): 852-858.

Regulation of $\mathrm{pH}$ in spermatozoa is a complex and dynamic process as sperm cells encounter different $\mathrm{pH}$ gradients during their journey from testes to the site of fertilization in female genital tract. The precise regulations of $\mathrm{pH}$ in sperm cells regulate the sperm functions such as motility, hyperactivity, capacitation, and acrosome reaction. Electrophysiological, pharmacological, and molecular studies have revealed the presence of different ion channels and exchanger systems which regulate intracellular $\mathrm{pH}$ in sperm cells as well as regulate sperm functions. Recent studies also have shown the potential involvement of $\mathrm{pH}$ in the regulation of fertility competence of sperm cells, and alterations in $\mathrm{pH}$ have shown to impede sperm functions. This mini-review discusses the probable mechanisms involved in $\mathrm{pH}$ regulation in sperm cells and how $\mathrm{pH}$ is involved in regulation of various sperm functions.

Keywords: acrosome reaction, capacitation, fertilization, $\mathrm{pH}$, sperm motility, spermatozoa.

\section{Introduction}

All biophysiological events in cells involving enzymes, hormones, transmitters, and growth factors are dependent on $\mathrm{pH}$. Any alteration in $\mathrm{pH}$ leads to either inhibition of function or deviation of cell function. Biological macromolecules have evolved to perform their function in specific cellular environment, and their dependency on $\mathrm{pH}$ for activity and stability reflects the significance of $\mathrm{pH}$. Proton (and proton equivalent) has a crucial role in eukaryotic cellular function as all proteins depend on $\mathrm{pH}$ to maintain their structure and function. Along with these, every individual organelle in a cell is capable of performing a function on establishment of $\mathrm{pH}$ gradient [1].

Spermatozoa are specialized cells with sole purpose to fertilize the oocyte and deliver its genetic information to next generation. On ejaculation, millions of sperm cells are released into female reproductive tract from which only a few reach their target. To reach the target after being released from gonads, sperm has to encounter inconsistent extracellular environment with fluctuating concentration of ions, $\mathrm{pH}$, pollutants, temperature, and other physiochemical variables which

Copyright: Mishra, et al. Open Access. This article is distributed under the terms of the Creative Commons Attribution 4.0 International License (http://creativecommons.org/licenses/by/4.0/), which permits unrestricted use, distribution, and reproduction in any medium, provided you give appropriate credit to the original author(s) and the source, provide a link to the Creative Commons license, and indicate if changes were made. The Creative Commons Public Domain Dedication waiver (http://creativecommons.org/ publicdomain/zero/1.0/) applies to the data made available in this article, unless otherwise stated. influence sperm behavior and metabolism [2]. Among these factors, $\mathrm{pH}$ could have a major initial effect on sperm activity and motility before as well as during the process of fertilization.

In mammalian seminiferous tubules and rete testis, sperm cells encounter $\mathrm{pH}$ of 7.2-7.4, which become 6.5 in caput epididymis and 6.7-6.8 in cauda epididymis $[3,4]$. During ejaculation, $\mathrm{pH}$ of semen becomes 7.2-7.4, and further after ejaculation into vagina, $\mathrm{pH}$ becomes 4.5-7.5, and in cervix, $\mathrm{pH}$ increases to 6.57.5 and ultimately in uterus and fallopian tube (7-7.8) (Figure-1) $[3,4]$.

Sperm is the only cell whose activity is outside the male body, and in the inconsistent chemical milieu of sperm, seminal plasma may have profound effects on sperm quality and $\mathrm{pH}$ is one of the most critical factors which determine the semen quality. Spermatozoa are highly affected by $\mathrm{pH}$. Functions such as motility, viability, capacitation, and acrosome reaction are $\mathrm{pH}$ dependent. During the journey in both male and female genital tract, sperm cell shows precise regulation of proton gradient and thereby regulation of intracellular $\mathrm{pH}$. Studies have shown deviated/disrupted sperm functions at high/low $\mathrm{pH}$ indicating the existence of dynamic $\mathrm{pH}$ regulatory system in spermatozoa [5]. Some studies related to the effect of $\mathrm{pH}$ in birds, fish, shellfish, and mammals have been done, and nearly, all the results show the promising effect of $\mathrm{pH}$ on sperm motility, viability, and capacitation.

Significance of $\mathrm{pH}$ in regulating functional dynamics of spermatozoa begins from the testis 


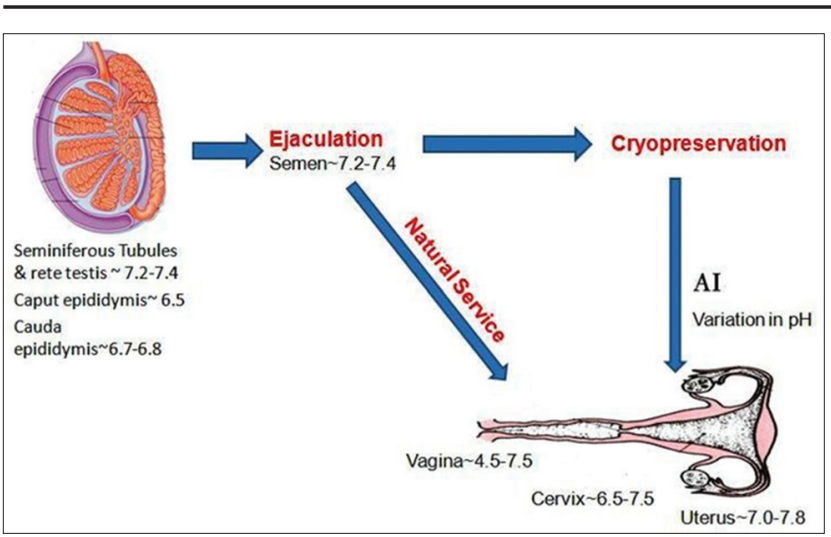

Figure-1: Different $\mathrm{pH}$ gradient in male and female genital tract implying a varying $\mathrm{pH}$ gradient for spermatozoa (Picture Courtesy: DKS, AKM and AK).

(spermatogenesis) to their storage in epididymis and further its movement along the male reproductive tract [3]. During sperm cell journey, there is an interaction with glandular secretions and thereby modulation in sperm behavior. All these components of seminal plasma are regulated by a tightly controlled buffering system $[5,6]$. Spermatozoa are bathed in seminal plasma which is complex fluid secretions of accessory sex glands of male reproductive system and potentially contains all active component required for the optimal regulation of $\mathrm{pH}$ in and around sperm cells $[4,6]$. From these, it is evident that sperm functions are regulated by $\mathrm{pH}$ of genital tract of both male and female. This regulation is very precise and controlled by dynamic ion regulation along the sperm membrane [2].

\section{pH Regulatory Mechanisms in Different Animals}

Fish

Fishes basically are adapted to aquatic life and show external fertilization. Spermatozoa are passed into water where they swim to reach the site of fertilization, and in this prospective, importance of water salinity comes into picture. Salinity of water regulates its $\mathrm{pH}$ and depends on both soluble and insoluble particulates [7]. Alteration in water $\mathrm{pH}$ not only affects spermatozoa function but also makes the spermatozoa incompetent to bring fertilization [8]. Ion concentration, osmotic pressure, $\mathrm{pH}$, temperature, and dilution of water affect sperm functional parameters [7].

$\mathrm{pH}$ has no direct effect on sperm function in fishes rather altered $\mathrm{pH}$ affects the endocrinological mechanisms associated with initiation of sperm motility. Altered $\mathrm{pH}$ in medium affects pituitary gonadotropin axis which remarkably alters the hormonal axis associated with the regulation of sperm functional dynamics [8]. Pituitary gland and gonadotropin stimulate the production of $17 \alpha$-hydroxyprogesterone in testicular somatic cells which markedly stimulate the production of $17 \alpha, 2 \beta$-dihydroxy-4-pregnen-3-one in spermatozoa, and this results in increased $\mathrm{pH}$ in sperm duct as well as increase in intrasperm cyclic adenosine 3',5' -monophosphate (cAMP) that initiates sperm motility. The hormone induced cAMP plays the cen tral role in regulating sperm motility [9].

Bird

$\mathrm{pH}$ regulation in birds spermatozoa is a critical process and is highly significant as birds do not exhibit separate tract for urine and spermatozoa. Both excretory wastes and reproductive cells pass through the same tract. Uricotelism results in the excretion of uric acid in excretory tract but does not affect the reproductive cell indicating a potential role of $\mathrm{pH}-\mathrm{reg}-$ ulating system in avian spermatozoa. The exact role of $\mathrm{pH}$ along the sperm membrane is not only clear but also studies have indicated a potential role of $\mathrm{pH}$ on endocrine axis of birds and ultimately regulating sperm function [10-13]. Spermatozoa are stored for long period of time in sperm storage tubules in female birds. These structures also mediate sustained and prolonged release of spermatozoa to the site of fertilization. After their release, complex interaction with temperature, $\mathrm{pH}$, ionic composition, and other factors occurs which regulate sperm motility. In domestic fowl, elevation in temperature from 30 to $40^{\circ} \mathrm{C}$ resulted in decrease motility, whereas alkalinization of external $\mathrm{pH}$ restored sperm motility at $40^{\circ} \mathrm{C}[10]$. Similar results were shown in turkey and quail, in terms of velocity and percentage of motile spermatozoa which are increased in alkaline $\mathrm{pH}$, and as compared to $30^{\circ} \mathrm{C}, 40^{\circ} \mathrm{C}$ requires more alkaline $\mathrm{pH}$ to initiate motility [11]. Body temperature (average $38.3^{\circ} \mathrm{C}$ ) and slightly alkaline condition seem to stimulate ostrich sperm motility; this response is similar to the previous studies in avian species [12]. Mechanism responsible for the quiescent stage of motile sperm in sperm storage tubule is unclear, but in quail, low oxygen and high lactic acid concentration were identified, and by lowering the $\mathrm{pH}$, motility was reduced [13].

\section{Mammals}

Mammals exhibit most complex mechanisms to regulate $\mathrm{pH}$ in spermatozoa. Past studies have demonstrated that mammalian spermatozoa display complex mechanisms to regulate intracellular $\mathrm{pH}$. The presence of Hv1channel (proton-gated channel) in mammalian spermatozoa has revealed the importance of $\mathrm{H}^{+}$ion in regulating sperm functional parameters [14]. The precise regulation of $\mathrm{H}^{+}$fluxing regulates intracellular sperm $\mathrm{pH}$ and also it associates with other ions to regulate $\mathrm{pH}$. The presence of $\mathrm{HCO}_{3}{ }^{-}$system further gives an idea regarding the complex mode of the regulation of $\mathrm{pH}$ [15]. It is also obvious that the movement of spermatozoa from testis to epididymis, in male and female reproductive tract encounters differential $\mathrm{pH}$ medium (as described earlier) but spermatozoa successfully reach the site of fertilization [14]. This gives rise to a dynamic concept of $\mathrm{pH}$ regulation in spermatozoa. The cytoplasmic $\mathrm{pH}$ of sperm could directly be affected by external $\mathrm{pH}$ of sperm with complex regulatory mechanism. Sperm intracellular $\mathrm{pH}$ exhibits a 
linear relationship with extracellular $\mathrm{pH}$ and studies have also shown that intracellular $\mathrm{pH}$ regulates ionic regulation along the sperm membrane [16].

Intracellular $\mathrm{pH}$ also regulates the opening of sperm-specific $\mathrm{Ca}^{++}$channel (CatSper) in sperm flagella, and this is the major ion channel that regulates sperm intracellular $\mathrm{Ca}^{++}$. Processes such as sperm hyperactivation, capacitation, and acrosome reaction are also associated with intracellular $\mathrm{Ca}^{++}$fluxing through CatSper channels [17,18]. Pharmacological and electrophysiological studies have revealed the precise role of $\mathrm{pH}\left(\mathrm{H}^{+}\right)$in regulation as well as activation of CatSper channels and thereby regulation of intracellular $\mathrm{Ca}^{++}$. Progesterone-mediated $\mathrm{Ca}^{++}$fluxing in spermatozoa is also governed by extrusion of $\mathrm{H}^{+}$from spermatozoa due to the activation of $\mathrm{Hvl}$ channels causing intracellular alkalization in spermatozoa [19].

Groundbreaking studies done by Babcock et al. [20] threw light on the role of internal $\mathrm{pH}$ in metabolism and motility of spermatozoa. They measured the cytosolic $\mathrm{pH}$ of bovine spermatozoa using fluorescein chromophore and showed that internal alkalization stimulates both motility and metabolism of epididymal bull spermatozoa. Intracellular $\mathrm{pH}$ is directly correlated with sperm motility, and in medium containing weak acids, sperm motility was suppressed as $\mathrm{pH}$ decreased. Reversible immobilization was established in this acidic medium, and after removal of weak acids, motility was restored up to $48 \mathrm{~h}$ in $\mathrm{CO}_{2}$ and up to $24 \mathrm{~h}$ in sperm dilution medium. This study revealed an inverse relationship between expression and conservation of sperm motility and depicts that intracellular acidification in spermatozoa suppresses motility and extend lifespan [21]. Studies in bovine spermatozoa have established the fact that intracellular $\mathrm{pH}$ substantially regulates sperm motility [20]. With the reduction in $\mathrm{pH}$ from 6.5 to 6 , the sperm motility was decreased linearly indicating the potential role of $\mathrm{pH}$ in the regulation of sperm motility. Controlled sperm studies keeping viscosity and temperature of follicular fluid constant with a variable $\mathrm{pH}$ resulted in alterations in sperm motility and thereby indicated the potential role of $\mathrm{pH}$ in regulating sperm motility [22]. Kinematic study on the effect of $\mathrm{pH}$ on bull sperm function revealed the higher value of kinetic parameters, membrane integrity, and mitochondrial activity at $\mathrm{pH} 7$ and 7.5 , while $\mathrm{pH}$ lower than 6.5 and above 8 resulted in compromised motility with a decrease in most of the parameters. The higher $\mathrm{pH}$ (8.5) immobilized spermatozoa through a significant reduction in mitochondrial activity [23]. With a high $\mathrm{pH}$, mitochondrial membrane potential decreases leading to the generation of the reduced amount of adenosine triphosphate (ATP). This results in reduced motility. Similarly, at an acidic pH (below 6.5), lower mitochondrial activity was observed leading to lower sperm motility. Optimal $\mathrm{pH}$ restores mitochondrial activity and thereby restores motility [23].
Analysis of internal $\mathrm{pH}$ of sperm in ram and boar in different ionic environment has shown a linear relationship between external $\mathrm{pH}$ and internal $\mathrm{pH}$. High external $\mathrm{pH}$ increased intracellular $\mathrm{pH}$ and initiated motility in boar epididymal spermatozoa. However, in ram, motility of sperm was less dependent on external $\mathrm{pH}$ and effect was non-significant [16]. In buck, intracellular $\mathrm{pH}$ was increased with the alterations in extracellular $\mathrm{pH}$ using dialyzed epididymal plasma and bicarbonate, and this initiated forward motility in goat caput-epididymal sperm. When the $\mathrm{pH}$ of media was elevated from 7 to 8 , about $55 \%$ cauda epididymal sperm became motile [24]. Motility of cauda epididymal sperm was studied in different $\mathrm{pH}$ in the presence and absence of motility inhibitory factor (MIF II). Lower $\mathrm{pH}$ (4.0-4.5) suppressed the motility and optimum $\mathrm{pH}$ for MIF II activity was observed between $\mathrm{pH} 6.5$ and 7.5; in alkaline $\mathrm{pH}$ above 7.5, MIF II activity was vanished [25]. Sperm forward motility promoting potency of motility initiating protein (MIP) was maximal at $\mathrm{pH} 8$ while neutral $\mathrm{pH}$ caused little activity of MIP [26]. Both the inhibitory factors and initiating protein show $\mathrm{pH}$ dependency for their activity.

Like other mammals, human spermatozoa also show dependency on $\mathrm{pH}$ for its functional activity [14]. Before fertilization, spermatozoa undergo capacitation and develop the ability to respond to the inducers of acrosome reaction and this development of acrosomal responsiveness is very much affected by $\mathrm{pH}[5,27]$. Studies have demonstrated that the internal $\mathrm{pH}$ had a positive relationship with external $\mathrm{pH}$. The decrease in external $\mathrm{pH}$ lowered the cytoplasmic $\mathrm{pH}$ and subsequently reduced the acrosomal responsiveness $[5,16]$. Although unesterified cholesterol of sperm must be lost in the process of acrosome reaction, the loss of cholesterol did not get affected by variation in $\mathrm{pH}$ [28]. When healthy human spermatozoa were cultured in sperm nutrition solution with varying $\mathrm{pH}$, sperm viability, motility, and hypoosmotic swelling rate were maximum at $\mathrm{pH} 7.2$ and decreased in more acidic and more basic medium [27]. Sperm $\mathrm{Na}^{+} / \mathrm{K}^{+}$-ATPase activity was lower at $\mathrm{pH} 5.2,6.2,8.2$, 9.2, and 10.2 as compared to $\mathrm{pH}$ 7.2. Alkalization of medium increased intracellular $\mathrm{Ca}^{2+}$ required for motility and capacitation [27]. Progressive motility and viability of sperm were decreased in acidic medium ( $\mathrm{pH} 5.2$ and 6.2), sperm penetration was higher at $\mathrm{pH} 7.2$ along with $\mathrm{Na}^{+} / \mathrm{K}^{+}$-ATPase activity, and $\mathrm{Ca}^{2+}$ influx decreased significantly in acidic environments [5].

Series of in vitro studies have documented as well as established the fact that $\mathrm{pH}$ is a significant player in regulating vital physiological functions of spermatozoa $[5,12,13,23]$. Studies also have indicated the existence of specific, accurate, and tightly regulated system to functionally regulate $\mathrm{pH}$ in spermatozoa $[4,14,15]$. $\mathrm{pH}$ regulation is also precise, and there may be the existence of other systems like 
ion channel regulatory systems to regulate $\mathrm{pH}$ in spermatozoa $[2,14,17,19]$. Figure-2 depicts the role of $\mathrm{pH}$ and its associated mechanism regulating sperm physiological functions.

\section{pH regulation}

Intracellular alkalinization is essential for triggering several physiological responses which are crucial for fertilization, and this proposes the existence of mechanisms to control internal $\mathrm{pH}$ [16]. The mechanism involved in proton transfer from cytoplasm across the sperm plasma membrane to extracellular environment is a species-specific event and along with it varies from cell to cell $[2,14]$. Due to the involvement of cells and species-specific mechanisms, the mechanisms of internal alkalization are still a topic of interest and investigation.

$\mathrm{pH}$ regulation in spermatozoa is regulated by three mechanisms, namely, $\mathrm{HCO}_{3}^{-}$influx, voltage-gated proton channel (Hv1), and $\mathrm{Na}^{+} / \mathrm{H}^{+}$exchanger (NHE). These three mechanisms have been extensively evaluated using molecular, pharmacological, and electrophysiological tools, and the studies have hypothesized the existence of these systems independently in spermatozoa and are regulated by different mechanisms (Figure-3).

\section{$\mathrm{HCO}_{3}{ }^{-}$influx system}

$\mathrm{HCO}_{3}^{-}$influx system involves the inward movement of $\mathrm{HCO}_{3}^{-}$which is essential for sperm capacitation. It produces cAMP by activating soluble adenylate cyclase ( $\mathrm{sAC}$ ) and promotes alkalinization and membrane hyperpolarization [29]. When
$\mathrm{Na}^{+}$is removed from the medium, then this alkalinization and hyperpolarization did not occur, indicating the presence of $\mathrm{Na}^{+} / \mathrm{HCO}_{3}^{-}$cotransport mechanism in spermatozoa [15]. $\mathrm{HCO}_{3}^{-}$entrance in sperm cytoplasm requires $\mathrm{Cl}^{-}$and sperm capacitation depends on both $\mathrm{Cl}^{-}$and $\mathrm{HCO}_{3}{ }^{-}$concentration [29].

Carbonic anhydrase (CA) catalyzes the reaction of hydration of $\mathrm{CO}_{2}$ and produces $\mathrm{HCO}_{3}^{-}$and regulates the homeostasis of $\mathrm{HCO}_{3}^{-}$in sperm. With the onset of puberty in mice, CA II and CA IV are expressed along the epididymal epithelium; CA II is located in principle piece of sperm and CA IV is present in the plasma membrane of entire sperm tail [30]. Experimentation has shown that CA II and CA IV knockout mice have imbalance $\mathrm{HCO}_{3}^{-}$homeostasis [30].

Cystic fibrosis transmembrane conductance regulator (CFTR) controls the $\mathrm{HCO}_{3}^{-}$entrance-dependent events in human sperm capacitation. Inhibition of CFTR affected $\mathrm{HCO}_{3}^{-}$entrance adversely and subsequently reduced the activation of cAMP/protein kinase A (PKA) pathway, demonstrating that CFTR and PKA activities are crucial for regulation of intracellular $\mathrm{pH}$ [31].

\section{NHE}

This mechanism involves proton transfer through NHE. Sperm-specific NHE is located in the flagellum and NHE-null mice were found sterile [32]. After leaving epididymis, spermatozoa encounter high $\mathrm{Na}^{+}$concentration in seminal fluid which favors the exchange of anions across the membrane. When cell-permeable cAMP analogs were added in NHE-null spermatozoa,

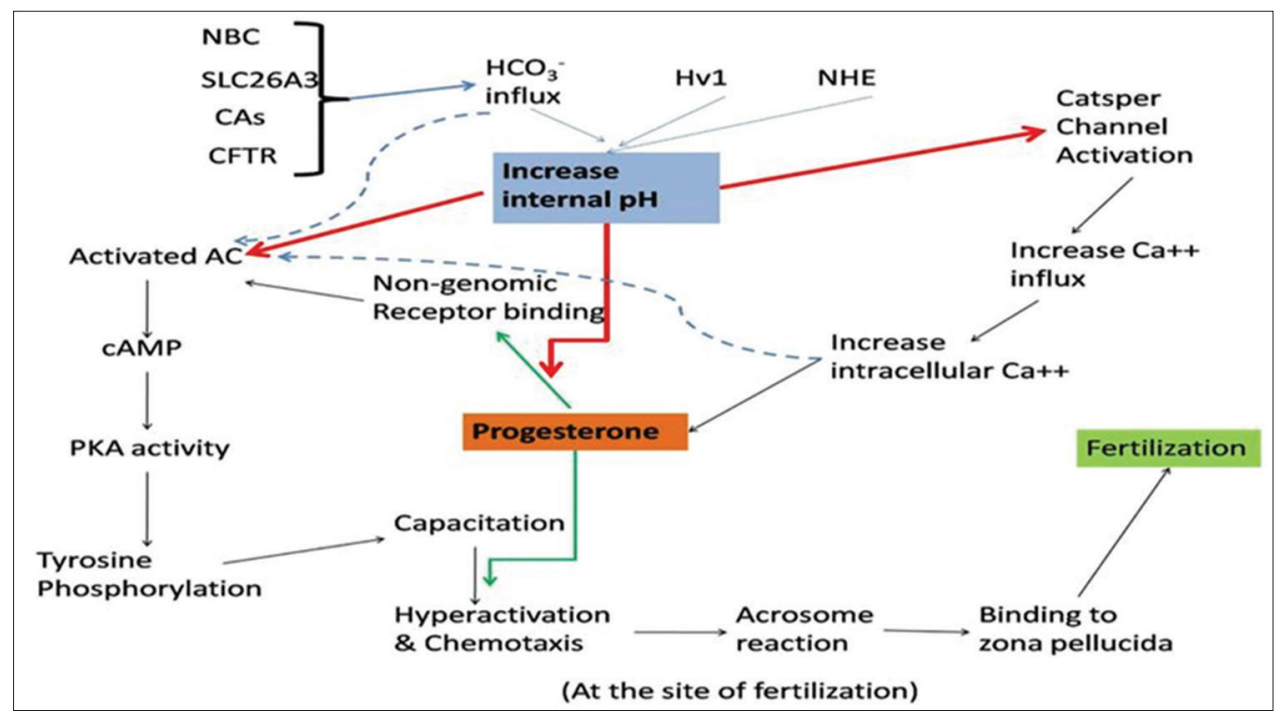

Figure-2: Schematic insight to regulation of $\mathrm{pH}$ in spermatozoa as well as dynamic signaling pathways in spermatozoa in terms of $\mathrm{pH}$-dependent mechanism. Appropriate intracellular $\mathrm{pH}$ is required for sperm functions to achieve successful fertilization to achieve successful fertilization. Regulation of $\mathrm{H}+$ influx is mediated by $\mathrm{HCO} 3-$, influx. Voltage-gated proton channel, $\mathrm{Na}+/ \mathrm{H}+$ exchanger $\mathrm{Na}+/ \mathrm{HCO} 3-\mathrm{co}$-transport, and $\mathrm{CI}-/ \mathrm{HCO} 3-$ exchanger (SLC26A3) are responsible for $\mathrm{HCO} 3-$ influx, so $\mathrm{Na}+$ and $\mathrm{CI}-$ are indirectly involved in $\mathrm{pH}$ regulation. Progesterone hormone binds to non-genomic receptor and is dependent on $\mathrm{pH}$. With influx of $\mathrm{HCO} 3-$ and $\mathrm{Ca}++$, enzyme-soluble adenylyl cyclase is activated which leads to increased generation of cyclic adenosine 3',5'-monophosphate and subsequent increased protein kinase A (PKA) activity. Increased PKA activity leads to phosphorylation of tyrosine-containing protein on spermatozoa which are the key players behind the induction of capacitation/hyperactivation. Eventually, these events mediate interaction of spermatozoa with oocyte resulting in fertilization. The action of progesterone is $\mathrm{pH}$ dependent and occurs in a dose-dependent manner (Picture Courtesy: AKM, AK and DKS). 


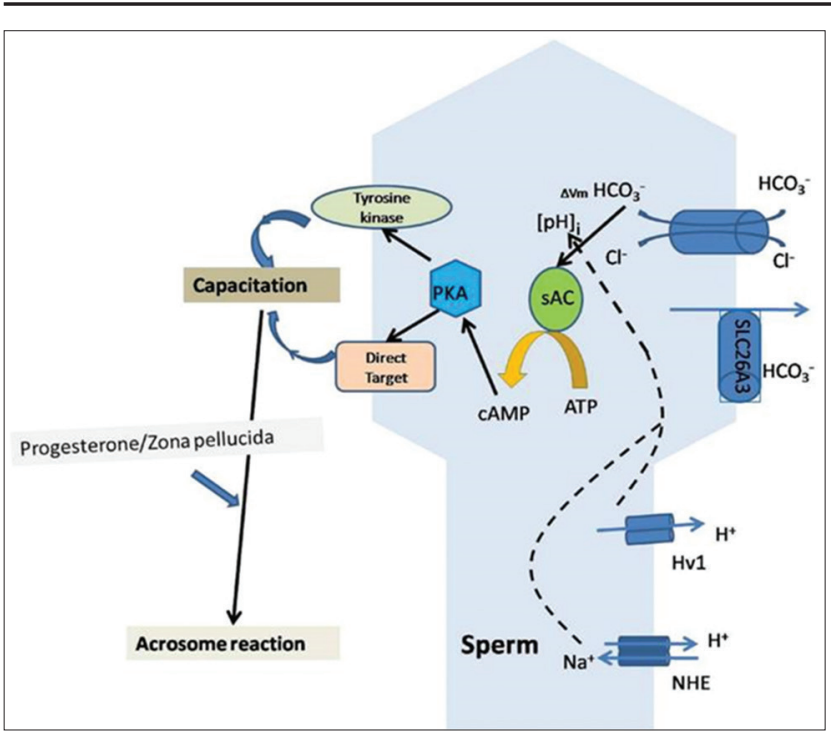

Figure-3: Regulation of sperm intracellular $\mathrm{pH}$ through three different mechanisms (Picture Courtesy: AKM, AK and DKS).

then it restored protein tyrosine phosphorylation activity and sperm motility in defective sperm suggesting the role of NHE in regulation of internal $\mathrm{pH}$ [32]. Male mice lacking NHEs (NHA1 and NHA2) gene are sterile with diminished sperm motility. When treatment of NHA1 antisera was given to mice, reduced sperm internal $\mathrm{pH}$ was observed and it caused immobility probably through attenuating SAC-mediated cAMP synthesis [33].

\section{Hv1}

Hv1 channel is an $\mathrm{H}^{+}$transporter across the membrane and composed of a voltage sensor domain homologous to the voltage sensor of voltage-gated cation channel [34]. In contrast to a conventional ion channel, Hv1 lacks a classical pore region [35]. Although Hv1 molecule dimerizes, each subunit can function independently as a Hv1 [36]. Hv1 was identified in human spermatozoa and abundantly localized in the principal piece of sperm flagellum, which is the ideal position to activate $\mathrm{pH}$-dependent protein of axoneme and thus to control sperm motility [37]. Hv1 is characterized by strong voltage dependence, activation by low intracellular $\mathrm{pH}$, unidirectional proton extrusion, inhibition by a low concentration of zinc, and potentiation by fatty acids [14]. Sperm Hv1 conducts proton much more rapidly and efficiently and conducts them unidirectionally to the extracellular space [38]. Hv1 channel is involved in the regulation of sperm internal $\mathrm{pH}$, and through this, almost every aspect of sperm function is get influenced in the female reproductive tract, including initiation of hypermotility, capacitation, hyperactivation, and acrosome reaction [14,37]. Sperm Hv1 can be activated by the removal of extracellular zinc, which is present in seminal plasma [39]. In female reproductive tract, any bound zinc is released through dilution or absorption by the uterine epithelium and chelation by albumin and other molecules cause the activation of Hv1 channel [40]. The low micromolar concentration of the endogenous cannabinoid anandamide strongly potentiates the sperm Hv1 [19].

\section{pH and infertility}

Mammalian fertilization is intricately regulated event comprising several known and unknown factors such as genetic, physiological, environmental, and managerial factors [2]. Determination of the exact causes of infertility is difficult due to its multi-factorial complex interaction with other factors. As mentioned in previous section, $\mathrm{pH}$ is a key regulator in sperm physiology and function, suggesting that improper $\mathrm{pH}$ homeostasis could be one of the reasons for unexplained infertility [5]. Usually, vaginal $\mathrm{pH}$ is acidic and in human ranges from 4.0 to 4.9 , and in other non-human mammals, vaginal $\mathrm{pH}$ is $6.8[3,41]$. Fluctuation in vaginal $\mathrm{pH}$ is observed which is mainly due to vaginal microbiome and hormonal variation in reproductive cycle. Lactic acid producing Lactobacilli and peak estrogen level are lower the vaginal $\mathrm{pH}$ [41]. The alkaline $\mathrm{pH}$ of semen defends sperm in acidic environment so inadequate semen volume or decreased alkalinity of seminal vesicular fluid may affect buffering capacity and result in compromised fertility [6]. Variation in vaginal $\mathrm{pH}$ makes reproductive tract more susceptible for infection, and inflammatory responses have been observed in infertile females with abnormal vaginal flora [42]. Colonization of sperm-agglutinating Staphylococcus aureus has been reported to cause immobility in spermatozoa [43].

Kidney disorders due to various diseases, poisoning of drugs, severe dehydration, and subacute ruminal acidosis in cattle could cause metabolic acidosis which brings down blood $\mathrm{pH}(7.4)[44,45]$. Chronic metabolic acidosis is associated with increased cortisol secretion [46], and this stress-induced rise of cortisol exerts inhibitory effect on the secretion of $\mathrm{LH}$ and testosterone which interfere with normal sperm production in testis. Ultimately, this chronic acidosis could be the reason for male infertility [45].

Development of artificial insemination (AI) technique is a boon in reproductive science and has been used intensively to boost the reproduction. Livestock farms, especially bovine, have used AI as their favorite tool for increasing production. After the collection of semen from superior sire, semen undergoes cryopreservation, and before preservation, semen is diluted with dilutors. Diluent $\mathrm{pH}$ is very much important for the maintenance of sperm respiration and motility. To counter $\mathrm{pH}$ changes, buffering agents are added to dilutors, and therefore, improper $\mathrm{pH}$ maintenance during freezing could affect efficiency of AI adversely [47].

Bacterial contamination is an inevident process during semen collection and processing of ultralow freezing. Microbial contamination results in a reduction in the $\mathrm{pH}$ of the diluents as well as this $\mathrm{pH}$ affect 
the overall quality of sperm cells. Studies have a shown significant reduction in sperm motility and viability in acidic $\mathrm{pH}$ during microbial contamination [48]. Due to low $\mathrm{pH}$, the post-thaw quality of spermatozoa also gets reduced and resulted in poor or compromised conception rates $[49,50] . \mathrm{pH}$ alteration is also associated with the alteration in medium osmolarity, and that is why functional alterations have been observed during freezing and thawing [50]. Therefore, in the context of semen freezing and $\mathrm{AI}, \mathrm{pH}$ of the medium, as well as $\mathrm{pH}$ during storage, plays a significant role in regulating sperm functional dynamics.

\section{Conclusion}

Precise regulation of sperm functional parameters in context to $\mathrm{pH}$ is still under investigation. Rapid changes in the external environment during sperm journey to oocyte are dynamically regulated by ion channels. $\mathrm{pH}$ plays a significant role in regulating sperm motility and fertility competence. That is why spermatozoa have developed dynamic $\mathrm{pH}$ regulatory systems by which there is a regulation of intracellular $\mathrm{pH}$. Intracellular $\mathrm{pH}$ is affected by extracellular $\mathrm{pH}$ and thereby opens many windows of investigation regarding the role of $\mathrm{pH}$ in functional significance of spermatozoa.

Increasing evidence of human male infertility in diabetic acidosis cases has raised many questions regarding the role of $\mathrm{pH}$ in spermatozoa functions. The multimeric approach is required to solve the mysteries behind $\mathrm{pH}$ and sperm functions. Understanding $\mathrm{pH}$ and its role in regulating spermatozoa function will help to develop strategies to understand and treat the basic causes behind infertility associated with $\mathrm{pH}$.

Cryopreservation-associated reduction in osmolarity and $\mathrm{pH}$ are critical regulators of sperm attributes after thawing. Altered $\mathrm{pH}$ has a negative effect on sperm functional competence. The use of buffers in dilutors solves these issues somehow, but still, it needs more improvement. Understanding the role of $\mathrm{pH}$ in the regulation of spermatozoa functions will help in the development of suitable agents which will restore $\mathrm{pH}$ during freezing and thawing.

\section{Author's Contributions}

$\mathrm{AKM}$ and $\mathrm{AK}$ designed and framed the manuscript as a part of their research under the supervision of DKS. RN and SY carried out the proofreading and finalized the manuscript and guided entirely during the preparation of this manuscript. DKS designed the concept and finalized the manuscript for publication. AKM, AK and DKS designed the figures for this review. All authors read and approved the final manuscript.

\section{Acknowledgments}

The authors thank the Vice-Chancellor, U.P. Pt. Deen Dayal Upadhyaya Pashu Chikitsa Vigyan Vishwavidyalaya, Mathura - 281001 , and the Dean,
College of Veterinary Science and Animal Husbandry for providing necessary facilities to carry out this work.

\section{Competing Interests}

The authors declare that they have no competing interests.

\section{References}

1. Casey, J.R., Grinstein, S. and Orlowski, J. (2010) Sensors and regulators of intracellular pH. Nat. Rev. Mol. Cell Biol., 11: $50-61$.

2. Darszon, A., Labarca, P., Nishigaki, T. and Espinosa, F. (1999) Ion channels in sperm physiology. Physiol. Rev., 79: 481-510.

3. Bonnie Ng, K.Y., Mingels, R., Morgan, H., Macklon, N. and Cheong, Y. (2018) In vivo oxygen, temperature and $\mathrm{pH}$ dynamics in the female reproductive tract and their importance in human conception: A systematic review. Hum. Reprod. Update, 24(1): 15-34.

4. Shum, W.W.C., Ruan, Y.C., Da Silva, N. and Breton, S. (2011) Establishment of cell-cell crosstalk in the epididymis: Control of luminal acidification. J. Androl., 32: 576-586.

5. Zhou, J., Chen, L., Li, J., Li, H., Hong, Z., Xie, M., Chen, S. and Yao, B. (2015) The semen $\mathrm{pH}$ affects sperm motility and capacitation. PLoS One, 10(7): e0132974.

6. Talluri, T.R., Mal, G. and Ravi, S.K. (2017) Biochemical components of seminal plasma and their correlation to the fresh seminal characteristics in Marwari stallions and Poitou jacks. Vet. World, 10(2): 214-220.

7. Wilson-Leedy, J.G., Kanuga, M.K. and Ingermann, R.L. (2009) Influence of osmolality and ions on the activation and characteristics of zebrafish sperm motility. Theriogenology, 71(7): 1054-1062.

8. Alavi, S.M.H. and Cosson, J. (2005) Sperm motility in fishes. I. Effects of temperature and $\mathrm{pH}$ : A review. Cell Biol. Int., 29(2): 101-110.

9. Nagahama, Y. (1994) Endocrine regulation of gametogenesis in fish. Int. J. Dev Biol., 38: 217-229.

10. Ashizawa, K., Wishart, G.J., Nakao, H., Okino, Y. and Tsuzuki, Y. (1994) Inhibition of temperature-dependent immobilization of fowl spermatozoa at body temperature by an increased intracellular pH. J. Reprod. Fertil., 101: 593-598.

11. Holm, L. and Wishart, G.J. (1998) The effect of $\mathrm{pH}$ on the motility of spermatozoa from chicken, turkey and quail. Anim. Reprod. Sci., 54: 45-54.

12. Bonato, M., Cornwallis, C.K., Malecki, I.A., RybnikTrzaskowska, P.K. and Cloete, S.W. (2012) The effect of temperature and $\mathrm{pH}$ on the motility and viability of ostrich sperm. Anim. Reprod. Sci., 133: 123-128.

13. Matsuzaki, M., Mizushima, S., Hiyama, G., Hirohashi, N., Shiba, K., Inaba, K., Suzuki, T., Dohra, H., Ohnishi, T., Sato, Y., Kohsaka, T., Ichikawa, Y., Atsumi, Y., Yoshimura, T. and Sasanami, T. (2015) Lactic acid is a sperm motility inactivation factor in the sperm storage tubules. Sci. Rep., 5: 17643.

14. Lishko, P.V., Botchkina, I.L., Fedorenko, A. and Kirichok, Y. (2010) Acid extrusion from human spermatozoa is mediated by Flagellar voltage-gated proton channel. Cell, 140(3): 327-337.

15. Demarco, I.A., Espinosa, F., Edwards, J., Sosnik, J., De La Vega-Beltran, J.L., Hockensmith, J.W., Kopf, G.S., Darszon, A. and Visconti P.E. (2003) Involvement of a $\mathrm{Na}+/$ HCO-3 cotransporter in mouse sperm capacitation. J. Biol. Chem., 278: 7001-7009.

16. Gatti, J.L., Chevrier, C., Paquignon, M., Dacheux, J.L. (1993) External ionic conditions, internal $\mathrm{pH}$ and motility of ram and boar spermatozoa. J. Reprod. Fertil., 98: 439-449.

17. Correia, J., Michelangeli, F. and Publicover, S. (2015) 
Regulation and roles of $\mathrm{Ca}^{2+}$ stores in human sperm. Reproduction, 150: R65-R76.

18. Ellinger I. (2016) The calcium-sensing receptor and the reproductive system. Front Physiol., 7: 371.

19. Lishko, P.V. and Kirichok, Y. (2010) The role of Hv1 and CatSper channels in sperm activation. J. Physiol., 588: 4667-4672.

20. Babcock, D.F., Rufo, G.A. Jr. and Lardy, H.A. (1983) Potassium-dependent increases in cytosolic $\mathrm{pH}$ stimulate metabolism and motility of mammalian sperm. Proc. Natl. Acad. Sci. USA, 80: 1327-1331.

21. Jones, J.M. and Bavister, B.D. (2000) Acidification of intracellular $\mathrm{pH}$ in bovine spermatozoa suppresses motility and extends viable life. J. Androl., 21: 616-624.

22. Rizvi, A.A., Quraishi, M.I. and Sarkar, V. (2009) The effect of $\mathrm{pH}$ and viscosity on bovine spermatozoa motility under controlled conditions. Int. Urol. Nephrol., 41: 523.

23. Contri, A., Gloria, D., Robbe, C., Valorz, L., Wegher, A. and Carluccio, A. (2013) Kinematic study on the effect of $\mathrm{pH}$ on bull sperm function. Anim. Reprod. Sci., 136(4): 252-259.

24. Jaiswal, B.S. and Majumder, G.C. (1998) Biochemical parameters regulating forward motility initiation in vitro in goat immature epididymal spermatozoa. Reprod. Fert. Dev., 10: 299-307.

25. Das, S., Saha, S., Majumder, G.C. and Dungdung, S.R. (2010) Purification and characterization of a sperm motility inhibiting factor from caprine epididymal plasma. PLoS One, 5(8): e12039.

26. Jaiswal, B.S., Das, K., Saha, S., Dungdung, S.R. and Majumder, G.C. (2010) Purification and characterization of a motility initiating protein from caprine epididymal plasma. J. Cell Physiol., 222: 254-263.

27. Chen, L., Ge, Y., Liang, Y. and Yao, B. (2014) Semen pH effects sperm motility and capacitation by influencing $\mathrm{Na} / \mathrm{K}$-ATPase activity and $\mathrm{Ca}$ concentration in spermoplasm. Transl. Androl. Urol., 3(S1): AB185.

28. Cross, N.L. (2007) Effect of $\mathrm{pH}$ on the development of acrosomal responsiveness of human sperm. Andrologia, 39: 55-59.

29. Chen, W.Y., Xu, W.M., Chen, Z.H., Ni, Y., Yuan, Y.Y., Zhou, S.C., Zhou, W.W., Tsang, L.L., Chung, Y.W., Hoglund, P., Chan, H.C. and Shi, Q.X. (2009) Cl-is required for $\mathrm{HCO} 3$-entry necessary for sperm capacitation in guinea pig: Involvement of a Cl-/HCO3-exchanger (SLC26A3) and CFTR. Biol. Reprod., 80: 115-123.

30. Wandernoth, P.M., Mannowetz, N., Szczyrba, J., Grannemannm, L., Wolf, A., Becker, H.M., Sly, W.S. and Wennemuth, G. (2015) Normal fertility requires the expression of carbonic anhydrases II and IV in sperm. J. Biol. Chem., 290: 29202-29216.

31. Puga, M.L.C., Pinto, N.A., Torres, R.P., Romarowski, A., Vicens, S.A., Visconti, P.E., Darszon, A., Trevino, C.L. and Buffone, M.G. (2017) Essential role of cftr in pka-dependent phosphorylation, alkalinization, and hyperpolarization during human sperm capacitation. J. Cell Physiol., 232(6): 1404-1414.

32. Wang, D., Hu, J., Bobulescu, I.A., Quill, T.A., McLeroy, P., Moe, O.W. and Garbers, D.L. (2007) A sperm-specific $\mathrm{Na}+/ \mathrm{H}+$ exchanger (sNHE) is critical for expression and in vivo bicarbonate regulation of the soluble adenylyl cyclase (sAC). Proc. Natl. Acad. Sci. USA, 104: 9325-9330.

33. Chen, S.R., Chen, M., Deng, S.L., Hao, X.X., Wang, X.X. and Liu, Y.X. (2016) Sodium-hydrogen exchanger NHA1 and NHA2 control sperm motility and male fertility. Cell Death Dis., 7: e2152.
34. Takeshita, K., Sakata, S., Yamashita, E., Fujiwara, Y., Kawanabe, A., Kurokawa, T., Okochi, Y., Matsuda, M., Narita, H., Okamura, Y. and Nakagawa, A. (2014) X-ray crystal structure of voltage-gated proton channel. Nat. Struct. Mol. Biol., 21: 352-357.

35. Ramsey, I.S., Mokrab, Y., Carvacho, I., Sands, Z.A., Sansom, M. and Clapham, D.E. (2010) An aqueous H+ permeation pathway in the voltage-gated proton channel Hv1. Nat. Struct. Mol. Biol., 17: 869-875.

36. Lee, S.Y., Letts, J.A. and Mackinnon, R. (2008) Dimeric subunit stoichiometry of the human voltage-dependent proton channel Hv1. Proc. Natl. Acad. Sci. USA, 105: 7692-7695.

37. Lishko, P.V., Kirichok, Y., Ren, D., Navarro, B., Chung, J.J. and Clapham, D.E. (2012) The control of male fertility by spermatozoan ion channels. Annu Rev. Physiol., 74: 453-475.

38. DeCoursey, T.E., Morgan, D., Musset, B. and Cherny, V.V. (2016) Insights into the structure and function of HV1 from a meta-analysis of mutation studies. J. Gen. Physiol., 148(2): 97-118.

39. Khan, M.S., Zaman, S., Sajjad, M., Shoaib, M. and Gilani, G. (2011) Assessment of the level of trace element zinc in seminal plasma of males and evaluation of its role in male infertility. Int. J. Appl. Basic Med. Res., 1: 93-6.

40. Lu, J., Stewart, A.J, Sadler, P.J., Pinheiro, T.J. and Blindauer, C.A. (2008) Albumin as a zinc carrier: Properties of its high-affinity zinc-binding site. Biochem. Soc. Trans., 36(6): 1317-1321.

41. Miller, E.A., Beasley, D.E., Dunn, R.R. and Archie, E.A. (2016) Lactobacilli dominance and vaginal $\mathrm{pH}$ : Why is the human vaginal microbiome unique? Front. Microbiol., 7: 1936.

42. Aboul Enien, W.M. and El Metwally, H.A. (2005) Association of abnormal vaginal flora with increased cervical tumour necrosis factor-alpha and interferon- gamma levels in idiopathic infertility. Egypt J. Immunol., 12(2): 53-59.

43. Kaur, S. and Prabha, V. (2012) Infertility as a consequence of sperm agglutinating Staphylococcus aureus colonization in genital tract of female mice. PLoS One, 7(12): e52325.

44. Pizzorno, J. (2015) Acidosis: An old idea validated by new research. Integr. Med. Clin. J., 14(1): 8-12.

45. Callaghan, M.J., McAuliffe, P., Rodgers, R.J., HernandezMedrano, J. and Perry, V.E.A. (2016) Subacute ruminal acidosis reduces sperm quality in beef bulls. J. Anim. Sci., 94: 3215-3228

46. Henger, A., Tutt, P., Riesen, W.F., Hulter, H.N. and Krapf, R. (2000) Acid-base and endocrine effects of aldosterone and angiotensin II inhibition in metabolic acidosis in human patients. J. Lab. Clin. Med., 136: 379-389.

47. Purdy, P.H. (2006) A review on goat sperm cryopreservation. Small Rumin. Res., 63(3): 215-225.

48. Sannat, C., Nair, A., Sahu, S.B., Sahasrabudhe, S.A., Kumar, A., Guptam A.K. and Shende, R.K. (2015) Critical sources of bacterial contamination and adoption of standard sanitary protocol during semen collection and processing in semen station. Vet. World, 8(5): 631-635.

49. Shukla, M.K. (2005) Correlation of microbial load of cryopreserved semen with quality of neat and cryopreserved Murrah buffalo bull semen. Buffalo Bull., 24: 84-87.

50. Rao, T.K.S., Mohanty, T.K., Chauhan, I.S. and Patel, N.B. (2014) Critical control points for quality semen production and utilization: An overview. Wayamba J. Anim. Sci., 6: 794-810. 